\title{
Differential Ontogenic Development of Three Receptors Comprising the NMDA Receptor/Channel Complex in the Rat Hippocampus
}

\author{
John W. McDonald, ${ }^{*}$ Michael V. Johnston, ${ }^{*}+\uparrow$ AND ANNE B. Young, $\S$
}

Departments of Neurology* and Pediatrics, $\dagger$ Johns Hopkins University and the Kennedy Research Institute, $\ddagger$

Baltimore, MD and Department of Neurology, $\$$ University of Michigan, Ann Arbor, MI (USA)

The postnatal development of the three receptor binding sites that constitute the $N$-methyl-D-aspartate (NMDA) receptor channel/complex was examined in six hippocampal regions of rats using quantitative receptor autoradiography. NMDA-sensitive $\left[{ }^{3} \mathrm{H}\right]-$ glutamate binding, strychnine-insensitive $\left[{ }^{3} \mathrm{H}\right] \mathrm{glycine}$ binding, and $\left[{ }^{3} H\right] N$-(1-[2-thienyl]cyclohexyl)-3,4-piperidine $\left(\left[{ }^{3} \mathrm{H}\right] \mathrm{TCP}\right)$ binding were measured to examine the ontogeny of NMDA recognition sites, glycine modulatory sites, and PCP receptors, respectively. NMDAsensitive $\left[{ }^{3} \mathrm{H}\right.$ ]glutamate binding transiently exceeded adult levels by 50 to $120 \%$ in all regions examined, with peak densities generally occurring between postnatal days (PND) 10 and 28 . Stratum radiatum $C A_{1}$ binding increased slowly from 49 to $61 \%$ of the adult value between PND 1 and 7, after which, binding rapidly rose to $151 \%$ of adult values at PND 14, remained elevated through PND 28, and then decreased to adult levels. The ontogenic profile of NMDA recognition site binding was similar in other hippocampal regions, although the initial age of maximal binding and the period of stabilization varied. The ontogenic profiles of glycine modulatory site binding and PCP receptor binding were very similar to each other. Development was delayed, however, with respect to NMDA recognition site binding. The rapid development of binding observed between PND 7 and 14 with NMDA receptors in stratum radiatum $\mathrm{CA}_{1}$ was contrasted by a much slower increase in glycine and PCP receptor binding. Furthermore, maximal glycine and PCP receptor binding densities were not reached until PND 28 and were lower than NMDA recognition site binding densities. The observed developmental patterns of binding to each of the receptor components of the NMDA receptor channel/complex are consistent with postnatal changes in cytoarchitecture, synaptogenesis, afferent lamination, and functional development of the hippocampus. However, the relative overexpression of NMDA recognition sites with respect to glycine and $P C P$ receptors between PND 7 and 21 suggests that there is differential expression of these binding sites during development. (c) 1990 Academic Press, Inc.

\section{INTRODUCTION}

Glutamate and structurally related excitatory amino acids (EAA) are the principle excitatory neurotransmitters in the mammalian brain. Physiological responses to glutamate are mediated by several receptor subtypes that are differentiated on the basis of preferential responses to synthetic and alkaloid agonists (66). Of the glutamate receptor subtypes, the NMDA receptor/ channel complex is best characterized (for review see (10)). This receptor complex consists of an NMDA recognition site coupled to a $\mathrm{Ca}^{2+}$ permeable cationic channel and several modulatory binding sites including receptors for glycine and dissociative anesthetics (phencyclidine, PCP, receptor). Physiological responses to NMDA are enhanced by glycine and reduced by PCP receptor ligands. The action of PCP receptor ligands is activity-dependent and blockade is produced by binding within the NMDA-associated ionophore.

Recent experimental data indicate that NMDA receptors have several physiological and pathophysiological roles in developing mammalian brain (for review see $(32,40))$. NMDA receptors participate in neurotransmission $(21,64)$ and are also involved in several developmental forms of activity-dependent synaptic plasticity including segregation of afferent visual input into eyespecific columns and long-term potentiation (LTP), a model of learning and memory $(4,9,20,25,53)$. NMDA receptor activation serves as a neurotrophic influence supporting neuronal cell growth and survival during restricted periods of postnatal development $(3,32,40,44$, 47). Excessive NMDA receptor activation, however, can produce neuronal injury and is implicated in the pathophysiology of neuronal injury resulting from hypoxiaischemia, sustained seizures, several developmental disorders of amino acid metabolism, and chronic neurodegenerative diseases $(7,33,40,55)$. The susceptibility of the brain to NMDA-mediated brain injury changes markedly during development; susceptibility peaks near postnatal day (PND) 7 in rats and the severity of injury at this stage is approximately 60 times greater than the 
TABLE 1

NMDA-Sensitive $\left[{ }^{3} \mathrm{H}\right]$ Glutamate, Strychnine-Insensitive $\left[{ }^{3} \mathrm{H}\right]$ Glycine, and $\left[{ }^{3} \mathrm{H}\right] \mathrm{TCP}$ Binding Densities in Adult Rats

\begin{tabular}{cccc}
\hline Hippocampal region & $\begin{array}{c}\text { NMDA-sensitive } \\
{\left[{ }^{3} \mathrm{H}\right] \text { glutamate binding }} \\
(100 \mathrm{nM})\end{array}$ & $\begin{array}{c}\text { Strychnine-insensitive } \\
\text { glycine binding }(100 \mathrm{n} M)\end{array}$ & $\begin{array}{c}\left.{ }^{3} \mathrm{H}\right] \mathrm{TCP} \text { binding } \\
(30 \mathrm{n} M)\end{array}$ \\
\hline SO, $\mathrm{CA}_{1}$ & $2.87 \pm 0.22$ & $2.21 \pm 0.11$ & $0.32 \pm 0.02$ \\
SR, CA 1 & $3.22 \pm 0.23$ & $2.45 \pm 0.15$ & $0.37 \pm 0.03$ \\
SO, CA & $1.66 \pm 0.15$ & $1.55 \pm 0.10$ & $0.19 \pm 0.01$ \\
SR, CA & $1.82 \pm 0.14$ & $2.39 \pm 0.14$ & $0.21 \pm 0.01$ \\
SMDG & $3.29 \pm 0.25$ & $0.65 \pm 0.03$ & $0.32 \pm 0.02$ \\
SUB & $0.86 \pm 0.05$ & $0.07 \pm 0.01$ & \\
\hline
\end{tabular}

Note. Binding values (pmol/mg protein) represent means $\pm \operatorname{SEM}(n=4)$. Adult rats $=$ PND 90. Abbreviations: SO, stratum oriens; SR, stratum radiatum; SMDG, stratum moleculare; dentate gyrus; SUB, subiculum dorsalis.

injury observed in adult brain on an equimolar basis $(23$, $35,40)$.

Recently autoradiographic receptor binding assays specific for glycine modulatory sites and PCP receptors have been developed. To determine whether the developmental expression of the three receptors that constitute the NMDA receptor complex are similar, this study compared the postnatal development of binding to NMDA recognition sites, glycine modulatory sites, and PCP receptors in the rat hippocampal formation using quantitative autoradiography. Preliminary results of these studies have been reported (39).

\section{MATERIALS AND METHODS}

A total of 31 male Sprague-Dawley albino rats at 8 postnatal ages (PND 1, 4, 7, 10,14, 21, 28, $90=$ adult, $n$ $=4$ /age except PND 21, $n=3$ ) were used to examine receptor ontogeny.

Tissue preparation. Animals were decapitated, and brains were rapidly removed and immediately frozen on dry ice. Twenty-micrometer horizontal frozen brain sections were thaw-mounted onto gelatin-coated slides and stored at $-20^{\circ} \mathrm{C}$ prior to receptor labeling $(<48 \mathrm{~h}$ storage time). Frozen storage for this time period does not affect binding parameters to any of the receptors examined in this study. Adjacent tissue sections were used to examine NMDA-sensitive $\left[{ }^{3} \mathrm{H}\right]$ glutamate, strychnine-insensitive $\left[{ }^{3} \mathrm{H}\right]$ glycine, and $\left[{ }^{3} \mathrm{H}\right]-N-(1-[2-$ thienyl]cyclohexyl)-3,4-piperidine ([$\left.\left.{ }^{3} \mathrm{H}\right] \mathrm{TCP}\right)$ binding in six hippocampal regions: stratum oriens (SO) and stratum radiatum (SR) of areas $\mathrm{CA}_{1}$ and $\mathrm{CA}_{3}$; area $\mathrm{CA}_{4}$; stratum moleculare of dentate gyrus (SMDG); and subiculum dorsalis (SUB).

NMDA-sensitive $\left[{ }^{3} \mathrm{H}\right]$ glutamatebinding. NMDA recognition sites were labeled with $\left[{ }^{3} \mathrm{H}\right]$ glutamate under conditions which select for binding to this site (modified from Ref. (17)). Sections were prerinsed for $30 \mathrm{~min}$ in 50 $\mathrm{m} M$ Tris-acetate, $\mathrm{pH} 7.4$, at $4^{\circ} \mathrm{C}$ and dried under cool air. Sections were incubated for $45 \mathrm{~min}$ at $4^{\circ} \mathrm{C}$ in the same buffer containing $100 \mathrm{nM}\left[{ }^{3} \mathrm{H}\right]$ glutamate, $2.5 \mu M$ quisqualate, and $1 \mu M$ kainate. These concentrations of quisqualate and kainate inhibit $>90 \%$ of $\left[{ }^{3} \mathrm{H}\right]$ glutamate binding to non-NMDA receptors. Additional sections from PND $1,4,10,14,21,28$, and 90 rats $(n=3$ /age) were incubated with $100 \mathrm{nM}\left[{ }^{14} \mathrm{C}\right]$ glutamate instead of $\left[{ }^{3} \mathrm{H}\right]$ glutamate. Nonspecific binding was determined in the presence of $500 \mu M$ NMDA, and at $100 \mathrm{nM}\left[{ }^{3} \mathrm{H}\right]-$ glutamate, it represented less than $10 \%$ of total binding at all ages. For saturation studies, the incubation buffer contained $40 \mathrm{nM}\left[{ }^{3} \mathrm{H}\right]$ glutamate and varying concentrations of unlabeled glutamate giving final concentrations of glutamate ranging from $40 \mathrm{nM}$ to $2.5 \mu M$. Sections were rapidly rinsed three times $(2 \mathrm{ml}$ each) with $50 \mathrm{mM}$ Tris-acetate $\left(4^{\circ} \mathrm{C}, \mathrm{pH} 7.4\right)$ followed by a final rinse $(2$ $\mathrm{ml})$ with an acetone/glutaraldehyde $(19: 1, \mathrm{v} / \mathrm{v})$ solution and rapidly dried under hot air.

Strychnine-insensitive $\left[{ }^{3} \mathrm{H}\right]$ glycine binding. Glycine modulatory sites were labeled with $\left[{ }^{3} \mathrm{H}\right]$ glycine under conditions that select for binding to this site (34). Sections were prerinsed for $30 \mathrm{~min}$ at $4^{\circ} \mathrm{C}$ in $50 \mathrm{mM}$ Trisacetate, $\mathrm{pH} 7.4$, and dried with cool air. Using the same buffer, sections were incubated for $35 \mathrm{~min}$ at $4^{\circ} \mathrm{C}$ with $100 \mathrm{nM}\left[{ }^{3} \mathrm{H}\right]$ glycine and $10 \mu M$ strychnine. This concentration of strychnine inhibits $\left[{ }^{3} \mathrm{H}\right]$ glycine binding to the inhibitory strychnine-sensitive glycine receptor. Nonspecific binding was determined with $1 \mathrm{mM}$ unlabeled glycine included in the incubation buffer and at $100 \mathrm{nM}$ $\left[{ }^{3} \mathrm{H}\right]$ glycine it represented less than $10 \%$ of total binding at all ages. In saturation studies, the incubation buffer included $40 \mathrm{nM}\left[{ }^{3} \mathrm{H}\right]$ glycine and varying concentrations of unlabeled glycine, providing total glycine concentrations ranging from $40 \mathrm{nM}$ to $2.5 \mu M$. Sections were rapidly rinsed following a protocol similar to the postrinse for the NMDA-sensitive $\left[{ }^{3} \mathrm{H}\right]$ glutamate binding assay.

$\left[{ }^{3} H\right] T C P$ binding. PCP receptors were labeled with $\left[{ }^{3} \mathrm{H}\right] \mathrm{TCP}(8,31)$. Sections were prerinsed for $30 \mathrm{~min}$ at 
$4^{\circ} \mathrm{C}$ in $50 \mathrm{mM}$ Tris-acetate, $\mathrm{pH} 7.4$, and dried. Sections were incubated for $45 \mathrm{~min}$ at $4^{\circ} \mathrm{C}$ in the same buffer containing $30 \mathrm{nM}\left[{ }^{3} \mathrm{H}\right] \mathrm{TCP}$ and $1 \mathrm{mM} \mathrm{Mg} \mathrm{Mg}^{2+}$. This concentration of magnesium maximally enhances $\left[{ }^{3} \mathrm{H}\right] \mathrm{TCP}$ binding (8). Nonspecific binding was determined in the presence of $200 \mu M$ TCP and at $30 \mathrm{nM}\left[{ }^{3} \mathrm{H}\right] \mathrm{TCP}$ it represented less than $15 \%$ of total binding at all ages. In saturation studies, the incubation buffer included $20 \mathrm{nM}$ $\left[{ }^{3} \mathrm{H}\right] \mathrm{TCP}$ and varying concentrations of unlabeled TCP, giving final total TCP concentrations ranging from 20 $\mathrm{n} M$ to $1 \mu M$. Sections were rinsed for $1 \mathrm{~min} 3$ times in 50 $\mathrm{m} M$ Tris-acetate $\left(4^{\circ} \mathrm{C}, \mathrm{pH} 7.4\right)$ containing $1 \mathrm{mM} \mathrm{Mg}^{2+}$ and dried.

Autoradiogram generation and data analysis. Sections were apposed to $\left[{ }^{3} \mathrm{H}\right]$ sensitive Ultrofilm (LKB), placed in an X-ray cassette for 3-8 weeks, and developed. A set of tritium standards (Amersham) calibrated against brain pastes with known amounts of radioactivity was coexposed with each film. Analyses of regional brain binding densities were determined densitometrically using a microcomputer-based video densitometer system (Imaging Research, St. Catherines, Ontario). Autoradiogram optical densities produced by labeled sections were compared to densities produced by calibrated standards and transformed to picomoles/milligram protein values using a computer-generated fourth order polynomial regression analysis. Regional brain binding densities (10 readings/brain region/section, bilaterally) were determined in three sections representing total binding and three sections representing nonspecific binding for each animal/receptor assay. Total specific binding was calculated as the difference between mean total and nonspecific binding for each animal. Values for animals at each age were averaged and are presented as means \pm SEM. Quantitative pseudo-color transformations of autoradiograms were prepared using a computer-based densitometer system.

Materials. L- $\left[{ }^{3} \mathrm{H}\right]$ Glutamate and $\left[{ }^{3} \mathrm{H}\right]$ glycine were purchased from Amersham. $\left[{ }^{3} \mathrm{H}\right] \mathrm{TCP}$ was purchased from Dupont. Unlabeled L-glutamate, NMDA, glycine, kainate, and strychnine were purchased from Sigma. Quisqualate (synthetic) was purchased from Cambridge Research Biochemicals.

\section{RESULTS}

\section{NMDA Recognition Sites}

In both laminae of the $\mathrm{CA}_{1}$ subfield, the developmental profile of NMDA-sensitive $\left[{ }^{3} \mathrm{H}\right]$ glutamate binding was similar although binding densities were always greater in SR compared with those in SO (Fig. 1A, Fig. 2 ). In SR, binding densities were $50 \%$ of adult values by PND 1 and increased slightly through PND 7 (Fig. 3). Binding rose markedly from PND 7 through PND 14 and at this age exceeded corresponding adult values by $50 \%$. Binding remained elevated through PND 28 and then declined to adult levels (Table 1).

The ontogenic profiles of NMDA-sensitive $\left[{ }^{3} \mathrm{H}\right]-$ glutamate binding in $\mathrm{SO}$ and $\mathrm{SR}$ of area $\mathrm{CA}_{3}$ were similar, with lower levels consistently present in SO (Fig. 4). In both laminae, the pattern of absolute binding densities between PND 1 and 7 paralleled densities in corresponding laminae of area $\mathrm{CA}_{1}$ (Fig. 2). However, maximal binding densities were reached earlier in area $\mathrm{CA}_{3}$. Binding exceeded adult values in both laminae between PND 10 and PND 28 and then declined.

In contrast to areas $C A_{1}$ and $\mathrm{CA}_{3}$, a different developmental pattern of NMDA-sensitive $\left[{ }^{3} \mathrm{H}\right]$ glutamate binding was found in SMDG (Figs. 2 and 5). Binding was $20 \%$ of adult values at PND 1 and there was a greater increase in binding from PND 1 to PND 4. Adult levels were present by PND 10; however, maximal binding was not attained until PND 28. The largest overshoot of NMDA-sensitive $\left[{ }^{3} \mathrm{H}\right.$ ]glutamate binding observed in any hippocampal area was found in the subiculum (Fig. 6). Adult values were present at PND 7 and binding exceeded adult values between PND 7 and PND 28. Maximal binding was observed between PND 10 (210\% of adult values) and PND 14 (220\% of adult values). However, in contrast to other hippocampal areas, binding declined rapidly from PND 14 to PND 21. Scatchard analysis of NMDA-sensitive $\left[{ }^{3} \mathrm{H}\right]$ glutamate binding indicated that the developmental changes in binding reflect mainly changes in the number of NMDA recognition sites (Table 2). The developmental pattern of $\left[{ }^{14} \mathrm{C}\right]$ glutamate binding to NMDA receptors in the hippocampus was similar to that of $\left[{ }^{3} \mathrm{H}\right]$ glutamate (Fig. 7).

\section{Glycine Modulatory Site and PCP Receptors}

The developmental patterns of strychnine-insensitive $\left[{ }^{3} \mathrm{H}\right]$ glycine binding to glycine receptors and $\left[{ }^{3} \mathrm{H}\right]-$ TCP binding to PCP receptors were very similar to each other but distinct from the pattern of NMDA recognition site binding. In contrast to the characteristic rapid increase in NMDA recognition sites after PND 7, both glycine and $\mathrm{PCP}$ receptor binding developed more gradually in corresponding hippocampal areas (Figs. 3-6). Unlike NMDA recognition site binding, transient overshoots of glycine and PCP receptor binding were not the norm. There was a trend, although not significant, for strychnine-insensitive $\left[{ }^{3} \mathrm{H}\right]$ glycine binding to exceed adult densities near PND 28 in all hippocampal regions. PCP receptor binding was not overexpressed in any hippocampal region. In both laminae of areas $\mathrm{CA}_{1}$ and $\mathrm{CA}_{3}$, the patterns of glycine and PCP receptor binding were similar although the absolute levels of binding were greater in SR than SO. Adult densities of glycine and PCP receptor binding were reached slightly earlier 


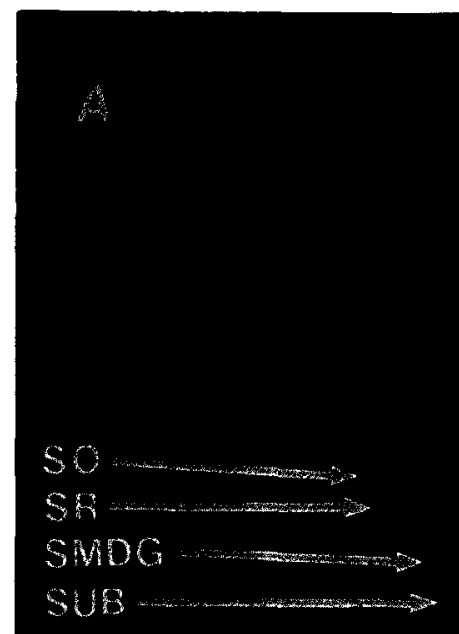






FIG. 2. Comparison of the development of NMDA-sensitive $\left[{ }^{3} \mathrm{H}\right]$ glutamate binding in stratum radiatum (s. rad.) of hippocampal subfields $\mathrm{CA}_{1}$ and $\mathrm{CA}_{3}$, stratum moleculare of the dentate gyrus (s. mol. DG), and subiculum. Data are expressed as means \pm SEM in pmol bound relative to protein ( $n=4$ /age except PND 21; $n=3$ ). The ontogenic profiles of binding were significantly different between brain hippocampal regions ( $P<0.001$, two-way ANOVA). Receptor binding assays were carried out as described under Materials and Methods.

in area $\mathrm{CA}_{3}(\mathrm{PND} 10)$ compared with area $\mathrm{CA}_{1}$ (between PND 14 and 21). In stratum moleculare of dentate gyrus, glycine and PCP receptor binding increased steadily from PND 1 through PND 21 when adult values were reached. In the subiculum, both glycine and PCP receptor binding reached adult values by PND 10 . Scatchard analysis of both strychnine-insensitive $\left[{ }^{3} \mathrm{H}\right]$ glycine binding and $\left[{ }^{3} \mathrm{H}\right] \mathrm{TCP}$ binding indicated that the developmental changes observed reflect mainly alterations in the number of binding sites (Table 2).

\section{DISCUSSION}

In this study, we have characterized the postnatal development of the three receptor components that constitute the NMDA receptor channel complex using quantitative receptor autoradiography. The results indicate that the binding to the three receptor components constituting the NMDA receptor complex is differentially expressed during postnatal development in the rat hippocampus. The ontogenic changes in each receptor appear to reflect changes mainly in the number of receptors rather than in the ligand-receptor affinity since Scatchard analyses of the data in PND 7 and adult animals indicated changes in $B_{\max }$ and not in $K_{D}$. Developmental alterations in the levels of endogenous receptor ligands are unlikely to explain the ontogenic and regional differences in receptor binding since these factors would be expected to alter receptor affinity. 'The affinity reported for $\left[{ }^{3} \mathrm{H}\right] \mathrm{TCP}$ binding in this study is similar to that of previous autoradiography studies (31) but is lower than that observed in homogenate studies.

The developmental patterns of binding to the receptor components of the NMDA receptor channel complex differed markedly among the six hippocampal regions. Several consistent developmental differences in binding between hippocampal regions were observed including the rate at which binding increased, the age when adult levels were reached, the age of peak binding, the magnitude of the overshoot of binding, and the length of time the overshoot was present. For instance, binding to each receptor component in both $\mathrm{SO}$ and $\mathrm{SR}$ of area $\mathrm{CA}_{3}$ reached adult levels earlier than binding in corresponding laminae in area $\mathrm{CA}_{1}$ (Fig. 2). These developmental patterns are consistent with the delayed neurogenesis, afferent lamination, and electrophysiological characteristics of area $\mathrm{CA}_{1}$ relative to area $\mathrm{CA}_{3}(5$, $29,57)$. The slower development of binding in SMDG relative to other hippocampal regions correlates with the late maturation of this area in terms of neurogenesis, afferent lamination, synaptogenesis, and development of $\operatorname{LTP}(5,11,13,28)$.

In general, the ontogenic profiles of glycine and PCP receptor binding were very similar to each other although $\left[{ }^{3} \mathrm{H}\right]$ glycine binding tended to exceed adult levels between PND 21 and PND 90, whereas transient overexpression of $\left[{ }^{3} \mathrm{H}\right] \mathrm{TCP}$ binding did not occur. In general, $\left[{ }^{3} \mathrm{H}\right]$ glycine and $\left[{ }^{3} \mathrm{H}\right] \mathrm{TCP}$ binding increased from birth and plateaued at adult values by PND 14. In contrast, NMDA-sensitive $\left[{ }^{3} \mathrm{H}\right]$ glutamate binding was markedly overexpressed in all hippocampal regions; binding to NMDA recognition sites peaked earlier, lasted longer, and was of greater magnitude than binding to the other receptor components. In general, binding increased slowly between PND 1 and PND 7, after which binding increased rapidly to adult densities between PND 7 and PND 14. Transient overshoots of

FIG. 1. Representative quantitative pseudo-color autoradiograms of (A) NMDA-sensitive $\left[{ }^{3} \mathrm{H}\right]$ glutamate (100 $\left.\mathrm{nM}\right)$ binding to NMDA recognition sites, (B) strychnine-insensitive $\left[{ }^{3} \mathrm{H}\right]$ glycine $(100 \mathrm{nM})$ binding to glycine modulatory sites, and (C) $\left.\left[{ }^{3} \mathrm{H}\right]\right]^{\mathrm{T}} \mathrm{CP}(30 \mathrm{n} M)$ binding to PCP receptors in hippocampi from PND 1, 4, 7, 10, 14, 21, and 28 rats. Note that the color scale bars in A, B, and C are different. Receptor binding assays were conducted as described under Materials and Methods. Abbreviations: SO, stratum oriens; SR, stratum radiatum; SMDG, stratum moleculare dentate gyrus; SUB, subiculum dorsalis. 

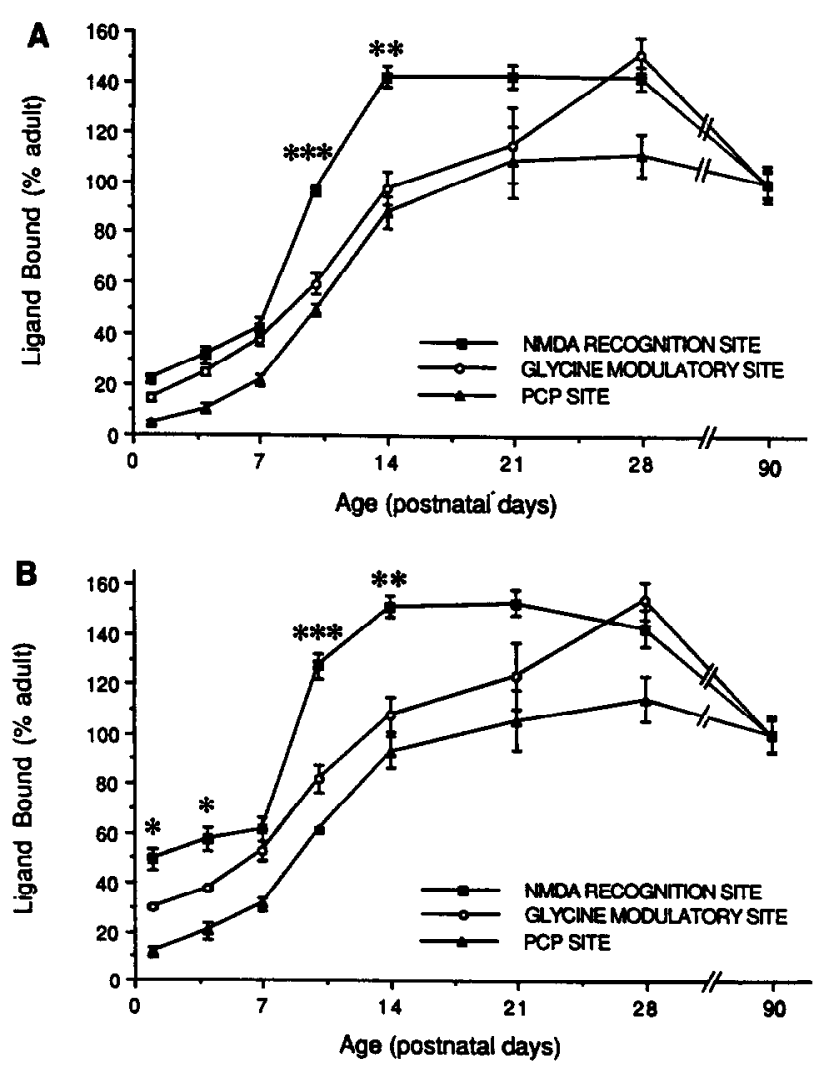

FIG. 3. Comparison of postnatal developmental profiles of NMDA-sensitive $\left[{ }^{3} \mathrm{H}\right]$ glutamate binding to NMDA recognition sites, strychnine-insensitive $\left[{ }^{3} \mathrm{H}\right]$ glycine binding to glycine modulatory sites, and $\left[{ }^{3} \mathrm{H}\right]$ TCP binding to PCP receptors in (A) stratum oriens and $(\mathrm{B})$ stratum radiatum of the $\mathrm{CA}_{1}$ hippocampal subfield. Data are expressed as percentage of adult values $=$ PND 90 (mean \pm SEM, $n$ $=4$ /age except PND 21, $n=3$ ). All animals were assayed at the same time and each receptor type was labeled in adjacent serial sections. Receptor binding assays were conducted as described under Materials and Methods. Adult binding densities are summarized in Table 1. The developmental profile of NMDA recognition site binding in both stratum oriens (A) and stratum radiatum (B) differed significantly from the corresponding profiles of both glycine and PCP receptor binding $(P<0.0001$, two-way ANOVA, NMDA vs glycine or PCP receptor binding by age). The ontogenic patterns of glycine and PCP receptor binding did not differ significantly $(P=$ n.s., two-way ANOVA, $\alpha=0.05$ ). NMDA recognition site binding in both stratum oriens (A) and stratum radiatum (B) was significantly greater than corresponding adult values at PND 14, 21, and $28(\alpha=0.05$, ANOVA with post-hoc Scheffe $F$ test $>4.2$ at PND 14,21 , and 28 ). ${ }^{*} P<0.01$, ${ }^{* *} P<0.005,{ }^{* * *} P<0.001$, two-tailed independent $t$ test, NMDA vs both glycine and PCP receptor binding at the same age.

binding were most common between PND 10 and PND 28; then binding decreased to adult levels.

The low-energy $\beta$ particles emitted by tritium are attenuated more by white matter than by grey matter $(2$, $27,52)$. Thus, it may be argued that the transient increase of NMDA receptor component binding may reflect developmental changes in myelination. However, the developmental profile of NMDA-sensitive $\left[{ }^{14} \mathrm{C}\right]-$ glutamate binding was similar to that of $\left[{ }^{3} \mathrm{H}\right]$ glutamate binding, indicating that the transient increase in binding is not the result of myelination occurring during late postnatal development (Fig. 7). Although, myelination may alter the developmental profile of binding slightly, it will not influence comparisons of binding to the individual NMDA receptor components within the same brain region.

\section{Previous Developmental Studies of NMDA Receptors}

Since the completion of these studies, several groups have examined independently the development of single
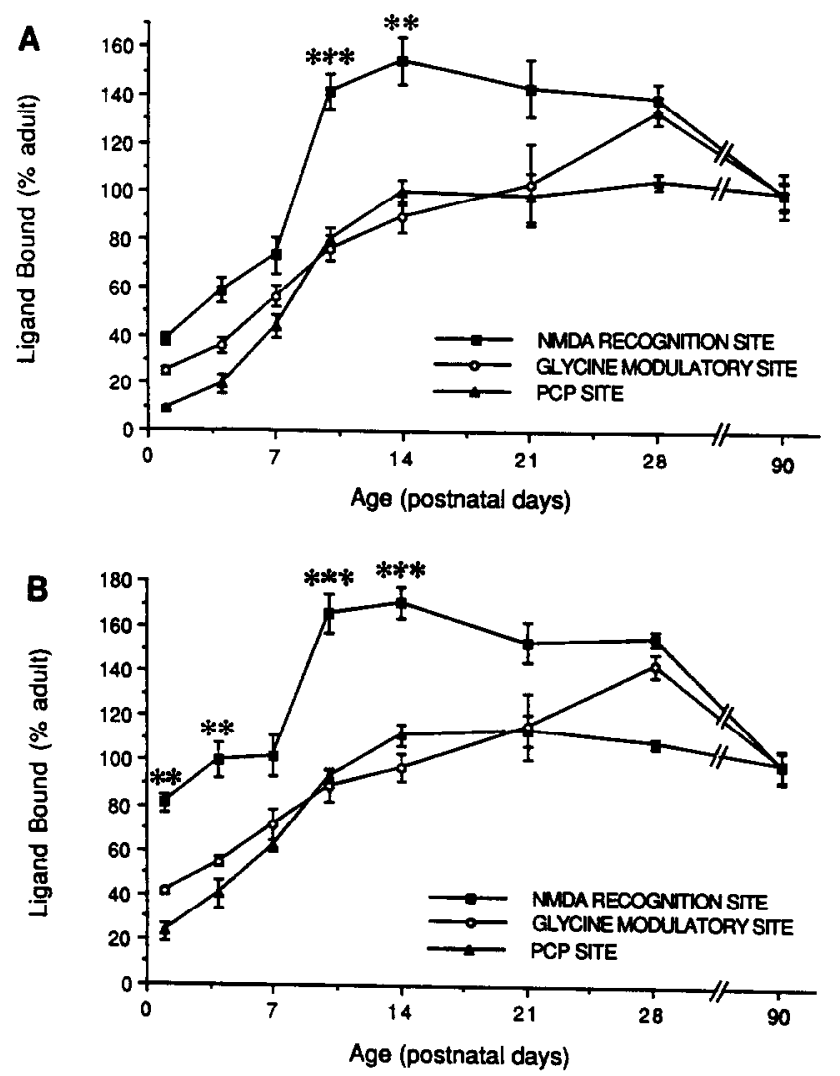

FIG. 4. Comparison of postnatal developmental profiles of NMDA-sensitive $\left[{ }^{3} \mathrm{H}\right.$ ]glutamate binding to NMDA recognition sites, strychnine-insensitive $\left[{ }^{3} \mathrm{H}\right]$ glycine binding to glycine modulatory sites, and $\left[{ }^{3} \mathrm{H}\right] \mathrm{TCP}$ binding to PCP receptors in (A) stratum oriens and (B) stratum radiatum of the $\mathrm{CA}_{\mathbf{a}}$ hippocampal subfield. Data are expressed as percentage of adult values $=$ PND $90($ mean $\pm \mathrm{SEM}, n$ $=4$ /age except PND 21, $n=3$ ). Development of NMDA recognition site binding in stratum oriens (A) and stratum radiatum (B) differed significantly from the developmental pattern of both glycine and PCP receptor binding in corresponding areas $(P<0.001$, two-way ANOVA, NMDA vs glycine or PCP receptor binding by age). Ontogeny of glycine and PCP receptor binding differed significantly in both laminae ( $P<0.05$, two-way ANOVA, glycine vs PCP by age). NMDA recognition site binding was significantly greater than corresponding adult densities at PND 10 and 14 in (A) stratum oriens and at PND $10,14,21$, and 28 in (B) stratum radiatum $(\alpha=0.05$, ANOVA with post-hoc Scheffe $F$ test $>4.5$ at each of these ages). ${ }^{* *} P<0.005,{ }^{* * *} P$ $<0.001$, two-tailed independent $t$ test, NMDA vs both glycine and $\mathrm{PCP}$ receptor binding at the same age. 


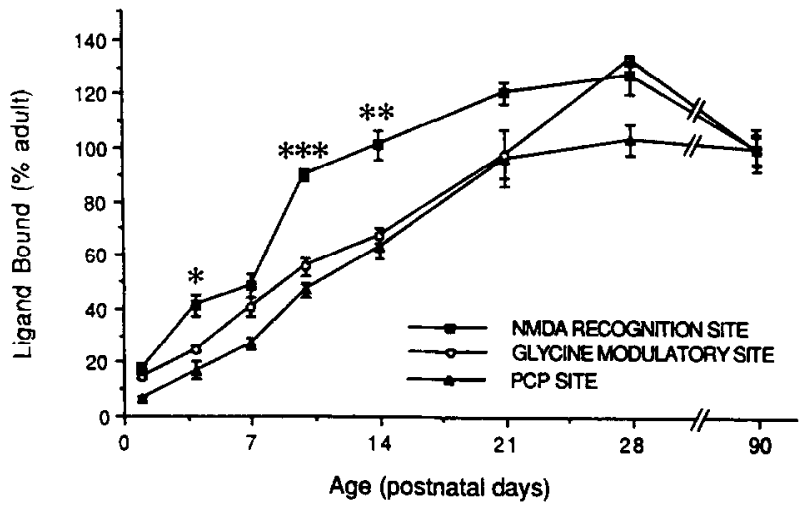

FIG. 5. Comparison of the postnatal developmental profiles of NMDA-sensitive $\left[{ }^{3} \mathrm{H}\right]$ glutamate binding to NMDA recognition sites, strychnine-insensitive $\left[{ }^{3} \mathrm{H}\right]$ glycine binding to glycine modulatory sites, and $\left[{ }^{3} \mathrm{H}\right] \mathrm{TCP}$ binding to PCP receptors in stratum moleculare of the dentate gyrus. See legend to Fig. 2 and Materials and Methods for other details. Ontogeny of NMDA recognition site binding was significantly different than the development of both glycine and PCP receptor binding $(P<0.001$, two-way ANOVA, NMDA vs glycine or PCP receptor binding by age). The developmental patterns of glycine and PCP receptor binding did not differ significantly $(P=$ n.s., twoway ANOVA, glycine vs PCP by age, $\alpha=0.05) .{ }^{*} P<0.01$, ${ }^{* *} P<0.005$, ${ }^{* * *} P<0.001$, two-tailed independent $t$ test, NMDA vs both glycine and PCP receptor binding at the same age.

components of the NMDA receptor channel complex. Tremblay et al. (65) initially described a transient increase in NMDA-sensitive $\left[{ }^{3} \mathrm{H}\right]$ glutamate binding in the rodent hippocampal $\mathrm{CA}_{1}$ subfield (stratum radiatum) using both frozen sections and tissue homogenates. In the autoradiographic study, a very broad developmental peak of binding was observed that exceeded adult values between PND 4 and 10. The discrepancies between the Tremblay study and our study with regard to the timing of the transient increase in NMDA receptor binding and the timing of the decrease to adult levels may reflect several methodologic differences including differences in preincubation and incubation conditions and the strain of rats. In contrast to the study by Tremblay et al. (65), the developmental pattern of NMDA-sensitive $\left[{ }^{3} \mathrm{H}\right]$ glutamate binding we observed matches closely with a similar autoradiographic study of NMDA-sensitive $\left[{ }^{3} \mathrm{H}\right]$ glutamate binding in rodent forebrain by Insel et al. (22). Overexpression of NMDA receptors have also been reported in postnatal human brain $(26,54)$.

The developmental expression of strychnine-insensitive $\left[{ }^{3} \mathrm{H}\right]$ glycine binding observed in the present study is similar to the developmental pattern of glycine modulatory site binding recently reported in another study using a synaptosomal preparation from whole rat forebrain (58). The gradual increase in $\left.{ }^{3} \mathrm{H}\right] \mathrm{TCP}$ binding from birth through PND 14 in the absence of a transient developmental peak observed in the $\mathrm{CA}_{1}$ and $\mathrm{CA}_{3}$ hippocampal subfields in our study is similar to the develop- ment of $\left[{ }^{3} \mathrm{H}\right] \mathrm{MK}-801$ binding to PCP receptors in a synaptosomal preparation of rodent hippocampus (43). Thus, our results are consistent with other studies of the NMDA receptor complex in the developing rat brain.

\section{Possible Mechanisms Contributing to the Relative Overexpression of NMDA Recognition Site Binding}

The relative overexpression of NMDA recognition site binding compared with glycine and PCP receptor binding may be related to several mechanisms or combination of mechanisms. Differential developmental expression of NMDA receptor complexes with varying ratios of component receptors could contribute to the relative overexpression of NMDA recognition sites. It is likely that multiple subclasses of NMDA receptor channel complexes exist as previously demonstrated for other macromolecular receptor channel complexes $(1$, $12,16,60)$; several biochemical and electrophysiological studies support this hypothesis $(6 \mathrm{a}, 14,15,34,42,48,49$, $56,61,62)$. Alternatively, the glutamate binding assay used in this study may only label a subset of NMDA receptors that has a pattern of development that is different from glycine and PCP receptor binding. Regionally and pharmacologically distinct agonist and antagonist preferring NMDA receptor complexes exist (42) and the glutamate binding assay used in this study may preferentially label one subset of binding sites. Developmental exposure of cryptic NMDA recognition sites

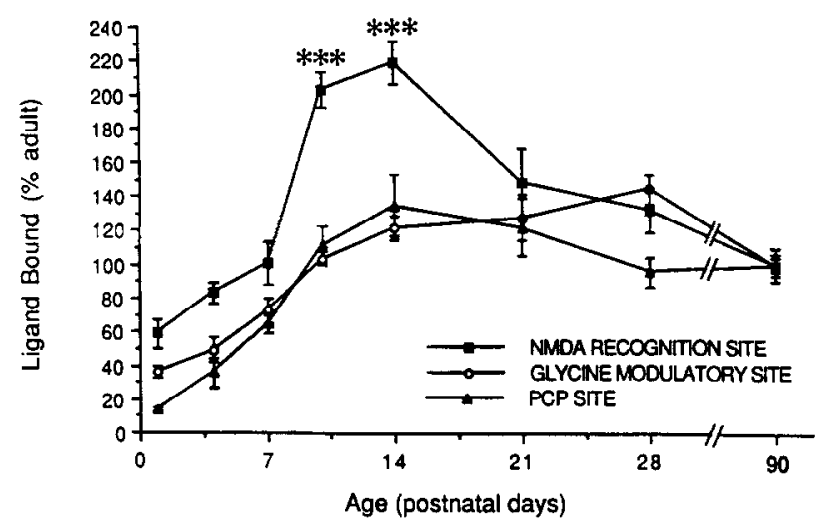

FIG. 6. Comparison of postnatal developmental profiles of NMDA-sensitive $\left[{ }^{3} \mathrm{H}\right]$ glutamate binding to NMDA recognition sites, strychnine-insensitive $\left[{ }^{3} \mathrm{H}\right]$ glycine binding to glycine modulatory sites, and $\left[{ }^{3} \mathrm{H}\right] \mathrm{TCP}$ binding to PCP receptors in the subiculum dorsalis. See legend to Fig. 2 and Materials and Methods for other details. The developmental pattern of NMDA recognition site binding was significantly different than development of either glycine or PCP receptor binding ( $P<0.001$, two-way ANOVA, NMDA vs glycine or PCP receptor binding by age). The developmental patterns of glycine and PCP receptor binding were similar $(P=$ n.s., two-way ANOVA, glycine vs PCP by age, $\alpha=0.05$ ). ${ }^{* *} P<0.001$, two-tailed independent $t$ test, NMDA vs both glycine and PCP receptor binding at the same age. 
TABLE 2

Comparison of Parameters of NMDA-Sensitive $\left[{ }^{3} \mathrm{H}\right]$ Glutamate, Strychnine-Insensitive $\left[{ }^{3} \mathrm{H}\right]$ Glycine, and $\left[{ }^{3} \mathrm{H}\right] \mathrm{TCP}$ Binding in SR $\mathrm{CA}_{1}$ of PND 7 and Adult Rats

\begin{tabular}{cccc}
\hline & $\begin{array}{c}\text { NMDA-sensitive } \\
{\left[{ }^{3} \mathrm{H}\right] \text { glutamate binding }}\end{array}$ & $\begin{array}{c}\text { Strychnine-insensitive } \\
{\left[{ }^{3} \mathrm{H}\right] \text { glycine binding }}\end{array}$ & {$\left[{ }^{3} \mathrm{H}\right]$ TCP binding } \\
\hline PND 7 & & & \\
$K_{D}(\mathrm{n} M)$ & $147 \pm 39$ & $191 \pm 21$ & $110 \pm 19$ \\
$B_{\max }(\mathrm{pmol} /$ mg protein $)$ & $3.6 \pm 0.2$ & $3.5 \pm 0.2$ & $0.64 \pm 0.09$ \\
Adult & $156 \pm 29$ & $196 \pm 10$ & $102 \pm 21$ \\
$K_{D}(\mathrm{n} M)$ & $8.8 \pm 0.3$ & $6.2 \pm 0.04$ & $2.1 \pm 0.19$ \\
$B_{\max }$ & & & \\
\hline
\end{tabular}

Note. Scatchard analyses of saturation isotherms were performed as described under Materials and Methods. Values represent specific binding (mean $\pm \mathrm{SEM}, n=4$ /assay).

could also contribute to the relative overexpression of NMDA recognition site binding. The effective coupling of NMDA recognition sites to glycine and PCP receptors appears not to change during development $(58,59)$ and therefore is not likely to contribute to the relative overexpression of NMDA recognition site binding. Developmental changes in non-NMDA receptors or glutamate uptake sites are not likely to substantially contribute to the apparent relative overexpression of NMDA receptors since the binding of glutamate to these sites is inhibited under the experimental conditions and NMDA receptor binding was determined as the amount of glutamate binding selectively displaced by NMDA. Whatever the mechanism, the developmental dissociation of binding to the component receptors of the NMDA receptor complex is consistent with previous biochemical studies that indicate that the maximal densities of NMDA, glycine, and PCP receptors can be individually regulated $(36,38,40,67)$.

\section{Relationships Between Developmental Changes in NMDA Receptor Binding and Physiology}

The physiological relevance of the overexpression of NMDA recognition site binding relative to binding to the other components of the NMDA receptor complex is unclear. However, the temporal overexpression of NMDA recognition site binding correlates with the development of several anatomical and physiological parameters. In the hippocampus, cellular differentiation and synaptogenesis are not complete at birth and these processes mature throughout postnatal development. In rodent areas $C_{1}$ and $C A_{3}$, the relative postnatal growth of the comissural/associational terminal fields and elaboration of SR pyramidal dendrites occur most rapidly during the second postnatal week and these changes parallel the maximal rate of change in NMDA recognition site binding $(29,41,50)$. The development of SMDG NMDA recognition sites parallels SMDG syn- aptogenesis (11). The greatest increase in synaptic density occurs between PND 4 and PND 11 with a slower rise to maximal synaptic densities at PND 25 (compare with Fig. 5). Also, dendritic growth and afferent lamination of the entorhinal terminal zone (stratum moleculare) of the dentate gyrus increase most rapidly between PND 4 and 10 and then rise more slowly to adult values (28).

The ontogeny of the receptor components that constitute the NMDA receptor channel complex may relate to several developmental changes in the physiology of EAA receptors. Postsynaptic excitation relative to inhibition predominates during the first postnatal weeks of hippocampal development as does enhanced seizure susceptibility $(18,20,51,57,63)$. In area $\mathrm{CA}_{3}$, superfusion of NMDA elicits recurrent synchronized burst activity; the epileptogenic effect of NMDA increases from PND 1 to PND 10 (24), which coincides with the development of NMDA receptor binding. Also, the susceptibility to convulsant-induced epileptiform activity increases from PND 4-6 to PND 14-16 (63). Specific NMDA receptor antagonists block this seizure activity (6). Developmental changes also occur in the chemosensitivity of $\mathrm{CA}_{1}$ pyramidal neurons to NMDA (19). The occurrence of maximal responses to NMDA between PND 12 and 30 in SR corresponds closely with the period of overproduction of NMDA receptors in this area (Fig. 3B). Furthermore, the ontogeny of area $\mathrm{CA}_{1}$ NMDA-sensitive $\left[{ }^{3} \mathrm{H}\right.$ ]glutamate binding parallels the development of LTP, an experimental model of learning and memory. In area $\mathrm{CA}_{1}$, the capacity for LTP is weak during the first postnatal week and increases until PND 15 when it transiently exceeds adult values (20). In the dentate gyrus, development of LTP is delayed with respect to area $\mathrm{CA}_{1}$, increasing through the first 3 postnatal weeks and transiently peaking near PND 30 , which is consistent with the delayed development of synaptic input and expression of NMDA recognition sites in dentate gyrus. These parallel findings between developmental expres- 

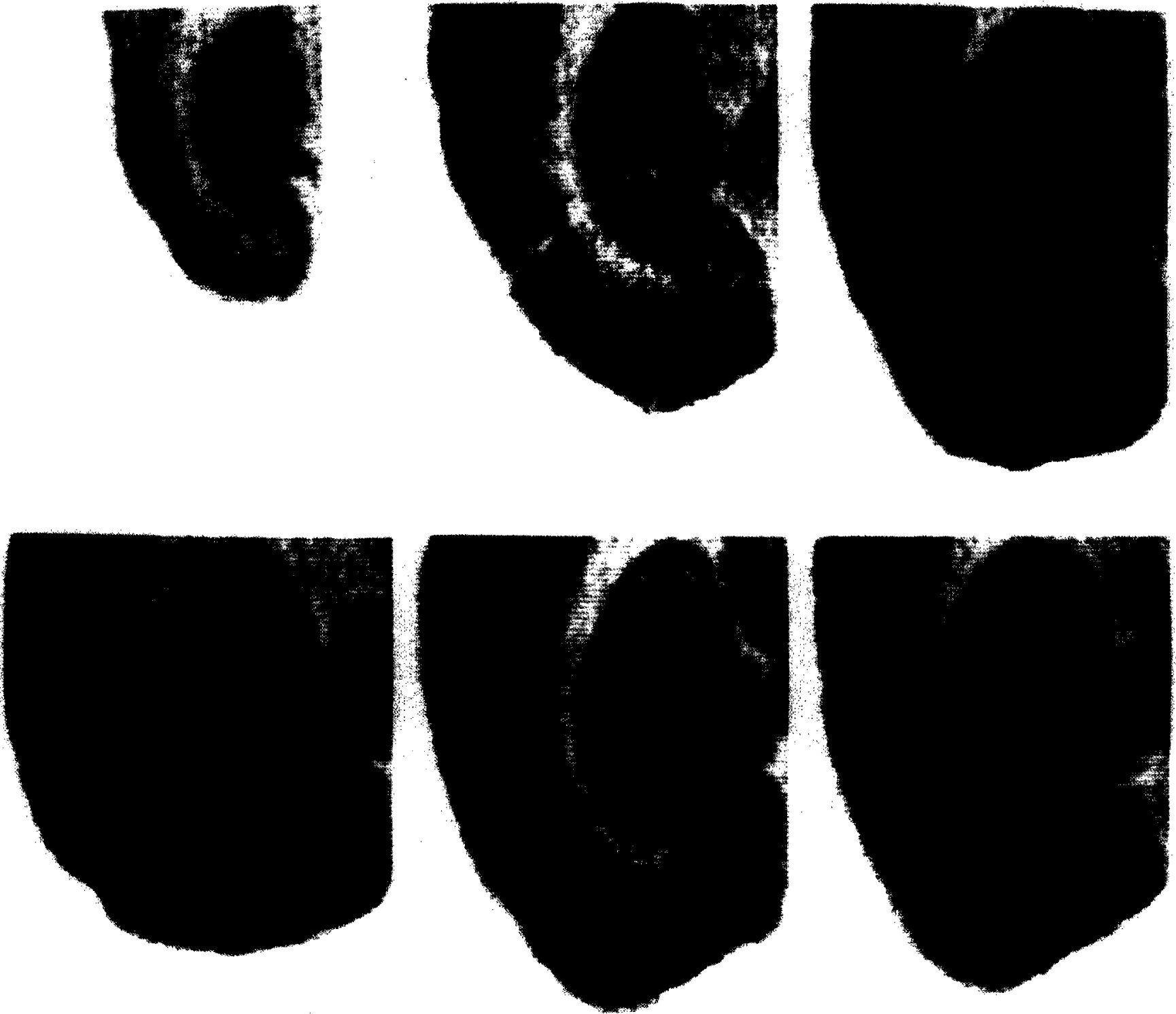

FIG. 7. Representative autoradiograms of the developmental expression of NMDA-sensitive $\left[{ }^{14} \mathrm{C}\right]$ glutamate binding in rat hippocampus. Numbers indicate the postnatal age of the animals from which the autoradiograms were generated. Sections were incubated with $100 \mathrm{n} M$ $\left[{ }^{14} \mathrm{C}\right]$ glutamate in $50 \mathrm{mM}$ Tris-acetate $\left(\mathrm{pH} 7.2,4^{\circ} \mathrm{C}\right.$ ) containing $2.5 \mu M$ quisqualate and $1 \mu M$ kainate. The developmental pattern of $\left[{ }^{14} \mathrm{C}\right]-$ glutamate binding is similar to that of the corresponding $\left[{ }^{3} \mathrm{H}\right]$ glutamate binding (see Fig. 1 ).

sion of NMDA recognition sites and LTP are intriguing since NMDA receptors play a critical role in formation of LTP (for review see Ref. (45)).

The susceptibility of the developing rodent brain to NMDA-mediated neurotoxicity transiently peaks near PND $7(23,35,40)$, after which toxicity decreases rapidly to adult values by PND 14. However, this pattern does not correlate with the absolute number of hippocampal NMDA receptors that peak between PND 10 and 28. The enhanced NMDA toxicity at PND 7 relates to the age at which NMDA-sensitive $\left[{ }^{3} \mathrm{H}\right]$ glutamate binding begins to rapidly increase. Several other devel- opmental factors may contribute to the transient enhanced toxicity of NMDA at PND 7.

EAA neurotransmitters participate in several developmental processes in addition to neurotransmission, such as regulation of neuronal growth and survival, synaptogenesis, and regulation of activity-dependent synaptic plasticity and $\operatorname{LTP}(3,9,32,40,45,47)$. However overactivation of NMDA receptors can also produce neuronal injury $(35,37,40)$. Thus an optimum level of excitation is required for normal development to proceed; too little activity could possibly delay or disrupt neuronal development and excessive activity could pro- 
duce neuronal injury (40). Since, EAA receptors appear to regulate synaptic plasticity and development of neuronal circuitry $(32,40)$, the ontogenic changes in the expression of the NMDA receptor components may relate to and/or regulate changes in synaptic plasticity, synaptogenesis, neuronal circuitry, and susceptibility to certain neurological diseases.

\section{ACKNOWLEDGMENTS}

This research was supported by USPHS Grant 1P01NS19613. J.W.M. is a recipient of a MSTP fellowship (5 T32 6M07863-07). K. O'Mara provided technical photography.

\section{REFERENCES}

1. AKaGi, H., AND MILEDI, R. 1988. Heterogeneity of glycine receptors and their messenger RNAs in rat brain and spinal cord. Science 242: $270-273$.

2. AleXander, G. M., R. J. Schwortzman, R. D. Bell, J. YU, AND A. RENTHAL. 1981. Quantitative measurement of local cerebral metabolic rate for glucose utilizing tritiated 2-deoxyglucose. Brain Res. 223: 59-67.

3. Balazs, R., O. S. JoRgensen, AND N. HACK. 1988. N-Methyl-Daspartate promotes the survival of cerebellar granule cells in culture. Neuroscience 27(2): 437-451.

4. Baudry, M., D. Arst, M. Oliver, AND G. Lrnch. 1981. Development of glutamate binding sites and their regulation by calcium in rat hippocampus. Dev. Brain Res. 1: 37-48.

5. BAYER, S. A. 1980. Development of the hippocampal region in the rat. I. Neurogenesis examined with ${ }^{3} \mathrm{H}$-thymidine autoradiography. J. Comp. Neurol. 190: 87-114.

6. BRADY, R. J., AND J. W. SWANN. 1986. Ketamine selectively suppresses synchronized afterdischarges in immature hippocampus. Neurosci. Lett. 69: 143-149.

6a. BRADY, R. J., AND J. W. SwANN. 1988. The effects of extracellular calcium on the epileptiform activity and NMDA responses are different in mature and immature hippocampal slices. Soc. Neurosci. Abstr. 14: 98.7.

7. CHOI, D. W. 1988. Glutamate neurotoxicity and diseases of the nervous system. Neuron 1: 623-634.

8. Chu, D. C. M., W. F. Makgos, J. B. Penney, and A. B. Young. 1981. Magnesium ions increase binding affinity of dissociative anesthetic receptors but not of NMDA receptors in rat brain. In Excitatory Amino Acid Research, Neurology and Neurobiology (E. A. Cavalheiro, J. Lehmann, and L. Turski, Eds.), pp. 567570. A. R. Liss, New York.

9. Cline, H. T., E. A. Debski, and M. Constatine-Paton. 1987. $N$-Methyl-D-aspartate receptor antagonist desegregates eyespecific stripes. Proc. Natl. Acad. Sci. USA 84: 4342-4345.

10. Cotman, C. W., AND L. L. Iversen. 1987. Excitatory amino acids in the brain-focus on NMDA receptors. Trends Neurosci. 10: 263-265.

11. Crain, B., C. Cotman, D. Taylor, and G. Lynch. 1973. A quantitative electron microscopic study of synaptogenesis in the dentate gyrus of the rat. Brain Res. 63: 194-204.

12. Deneris, E. S., J. ConNolly, J. Boulter, E. WADA, K. Wada, L. W. Swanson, J. Patrick, and S. Heinemann. 1988. Primary structure and expression of $\beta_{2}$ : A novel subunit of neuronal nicotinic acetylcholine receptors. Neuron 1: 45-54.
13. DuFfy, C. J., AND T. J. TEYLER. 1978. Development of potentiation in the dentate gyrus of rat: Physiology and anatomy. Brain Res. Bull. 3: 425-430.

14. Foster, G. A., AND P. J. RoBerts. 1980. Pharmacology of excitatory amino acid receptors mediating the stimulation of rat cerebellar cyclic GMP levels in vitro. Life Sci. 27: 215-221.

15. Ffrench-Mullen, J. M. H., N. Hori, and D. O. Carpenter. 1986. A comparison of the effects of quinolinate and NMDA on neurones in rat pyriform cortex. Neurosci. Lett. 63: 66-70.

16. Goldman, D., E. Deneris, W. Luyten, A. Kockhar, J. PatRICK, AND S. HEINEMANN. 1987. Members of a nicotinic acetylcholine receptor gene family are expressed in different regions of the mammalian central nervous system. Cell 48: 965-973.

17. Greenamyre, J. T., J. M. M. Olson, J. B. Penney, and A. B. YouNG. 1985. Autoradiographic characterization of $N$-methylD-aspartate, quisqualate- and kainate-sensitive glutamate binding sites. J. Pharmacol. Exp. Ther. 233: 254-263.

18. Haglund, M. M., AND P. A. SchWartzkroin. 1984. Seizure-like spreading depression in immature rabbit hippocampus in vitro. Dev. Brain Res. 14: 51-59.

19. Hamon, B., AND U. HEINEMANN. 1988. Developmental changes in neuronal sensitivity to excitatory amino acids in area CA1 of the rat hippocampus. Dev. Brain Res. 38: 286-290.

20. Harris, K. M., AND T. J. TeYLer. 1984. Developmental onset of long-term potentiation in area CAl of the rat hippocampus. $J$. Physiol. 346: 27-48.

21. Herron, C. E., R. A. J. Lester, E. J. Coan, AND G. L. CollingRIDGE. 1985. Intracellular demonstration of an $N$-methyl-Daspartate receptor mediated component of synaptic transmission in rat hippocampus. Neurosci. Letts. 60: 19-23.

22. INSEL, T. R., L. P. MILLER, AND R. E. Gelhard. 1990. The ontogeny of excitatory amino acid receptors in rat forebrain. I. $N$ Methyl-D-aspartate and quisqualate receptors. Neuroscience 35: $31-43$.

23. IKonomidou, C., J. Mosinger, K. Sallas Shahid, J. LABRUYERA, AND J. W. OLNEY. 1989. Sensitivity of the developing rat brain to hypobaric/ischemic damage parallels sensitivity to $N$-Methyl-D-aspartate neurotoxicity. J. Neurosci. 9: 28092818.

24. KING, A. E., E. Cherubini, AND Y. Ben-ARI. 1989. $N$-Methyl-Daspartate induces recurrent synchronized burst activity in immature hippocampal CA3 neurones in vitro. Dev. Brain Res. 46: 1-8.

25. KLEINSCHMIDT, A., M. F. BEAR, AND W. Singer. 1987. Blockade of "NMDA" receptors disrupts experience-dependent plasticity of kitten striate cortex. Science 238: 355-358.

26. Kornhuber, J., W. Retz, P. Riederer, H. Heinsen, AND J. FriTze. 1988. Effect of antemortem and postmortem factors on $\left[{ }^{3} \mathrm{H}\right]$ glutamate binding in the human brain. Neurosci. Lett. 93: 312-317.

27. KUHAR, M. J., AND J. R. UNNERSTALl. 1985. Quantitative receptor mapping by autoradiography: Some current technical problems. Trends Neurosci. 8: 49-53.

28. LoY, R., J. LYNCH, AND C. CoTMAN. 1977. Development of afferent lamination in the fascia dentata of the rat. Brain Res. 121: 229-243.

29. LOY, R. 1980. Development of afferent lamination in Ammon's horn of the rat. Anat. Embryol. 159: 257-275.

30. Majewska, M. D., S. Parameswaran, T. Vu, and E. D. LonDON. 1989. Divergent ontogeny of sigma and phencyclidine binding sites in the rat brain. Dev. Brain Res. 47: 13-18.

31. Maragos, W. F., J. B. Penney, AND A. B. Young. 1988. Ana- 
tomic correlation of NMDA and $\left[{ }^{3} \mathrm{H}\right]-\mathrm{TCP}$-labeled receptors in rat brain. J. Neurosci. 8: 493-501.

32. Matrson, M. P. 1988. Neurotransmitters in the regulation of neuronal cytoarchitecture. Brain Res. Rev. 13: 179-212.

33. McDonald, J. W., F. S. Silverstein, and M. V. Johnston. 1987. MK-801 protects the neonatal brain from hypoxic-ischemic damage. Eur. J. Pharmacol. 140: 359-361.

34. McDonald, J. W., J. B. Penney, M. V. Johnston, and A. B. YouNG. 1990. Characterization and regional distribution of strychnine-insensitive $\left[{ }^{3} \mathrm{H}\right]$ glycine binding sites in rat brain by quantitative receptor autoradiography. Neuroscience 35: 653668.

35. McDonald, J. W., F. S. Silverstein, and M. V. Johnston. 1988. Neurotoxicity of $N$-Methyl-D-aspartate is markedly enhanced in developing rat central nervous system. Brain Res. 459: 200-203.

36. MCDonald, J. W., F. S. Silverstein, AND M. V. Johnston. 1990. MK-801 pretreatment enhances NMDA-mediated brain injury and increases brain NMDA recognition site binding in rats. Neuroscience, in press.

37. MCDonald, J. W., F. S. Silvverstein, and M. V. Johnston. 1989. Neuroprotective effects of MK-801, 'TCP, PCP, and CPP against $N$-methyl-D-aspartate induced neurotoxicity in an in vivo perinatal rat model. Brain Res. 490: $33-40$.

38. McDonald, J. W., T. Hood, C. Sackellares, E. A. Garofalo, B. KHAHIL, P. MCKeEVER, S. GILMAN, J. Troncoso, AND M. V. JoHNSTON. 1989. Temporal lobe epilepsy: Excitatory and inhibitory amino acid receptor binding changes in excised hippocampus. Epilepsia 30: 719.

39. McDonald, J. W., M. V. Johnston, And A. B. Young. 1989. Ontogeny of the receptors comprising the NMDA receptor channel complex. Soc. Neurology Abstr. 15: 198.

40. McDonald, J. W., and M. V. Johnston. 1990. Physiological and pathophysiological roles of excitatory amino acids during central nervous system development. Brain Res. Rev. 15: 41-70.

41. MiNkwIT7, H. G. 1976. Entwicklung der Neuronenstruktur des Hippocampus wahrend der pri und postnatalen Ontogenese der Albinoratte 1. Mitteilung: Neurohistologische Darstellung der Entwicklung langaxoniger Neurone aus den Regionen CA3 and CA4. J. Hirnforsch. 17: 213-231.

42. Monaghan, D. T., H. I. Olverman, L. Ngujen, .J. C. Watkins, AND C. W. COTMAN. 1988. Two classes of $N$-methyl-D-aspartate recognition sites: Differential distribution and differential regulation by glycine. Proc. Natl. Acad. Sci. USA 85: 9836-9840.

43. Morin, A. M., H. Hattorl, C. G. Wasterlain, and Thomson, D. 1989. $\left[{ }^{3} \mathrm{H}\right] \mathrm{MK}-801$ binding sites in neonate rat brain. Brain Res. 487: 376-379.

44. Nelson, P. G., D. E. Grenneman, I. Forsythe, T. Nrcol, AND G. WESTBROOK. 1987. NMDA antagonists increase neuronal death without blocking electrical activity in developing cultures. Soc. Neurosci. Abstr. 13: 9 .

45. Nicoll, R. A., J. A. Kanuer, and R. C. Malenka. 1988. The current excitement in long-term potentiation. Neuron 1: 97 103.

46. Palacios, J. M., D. L. Niehoff, AND M. J. Kuhar. 1979. Ontogeny of GABA and benzodiazepine receptors: Effects of Triton $X-100$, bromide and muscimol. Brain Res. 179: 390-395.

47. Pearch, I. C., M. A. Cambray-Deakin, and R. D. Burogyne. 1987. Glutamate acting on NMDA receptors stimulates neurite outgrowth from cerebellar granule cells. FEBS Lett. 223: 143147.
48. Perkins, M. N., And T. W. Stone. 1983. Quinolinic acid: Regional variations in neuronal sensitivity. Brain Res. 259: $172-$ 176.

49. Perkins, M. N., AND T. W. Stone. 1985. Actions of kynurenic acid and quinolinic acid in the rat hippocampus in vivo. Exp. Neurol. 88: 570-579.

50. PoKornY, J., AND T. YAMAMOTo. 1981. Postnatal ontogenesis of hippocampal CA1 area in rats. I. development of dendritic arborisation in pyramidal neurons. Brain Res. Bull. 7: 113-120.

51. Purpura, D. P., S. Prelevic, and M. Santini. 1968. Postsynaptic potentials and spike variations in the feline hippocampus during postnatal ontogenesis. Exp. Neurol. 22: 408-422.

52. RaInBow, T. C., A. BIEgON, AND D. J. BERCK. 1984. Quantitative receptor autoradiography with tritium-labeled ligands: Comparison of biochemical and densitometric measurements. J. Neurosci. Methods 11: 231-241.

53. RAUSCHECKER, J. P., AND S. HAHN. 1987. Ketamine-xylazine anaesthesia blocks consolidation of ocular dominance changes in kitten visual cortex. Nature (London) 326: 183-185.

54. Represa, A., E. Tremblay, AND Y. Ben-ArI. 1987. Transient increase of NMDA-binding sites in human hippocampus during development. Neurosei. Lett. 99: 61-66.

55. Rothman, S. M., AND J. W. OlNey. 1987. Excitotoxicity and the NMDA receptor. Trends Neurosci. 10: 299-302.

56. Schwarcz, R., W. O. Whetsell, and R. M. Mangano. 1983. Quinolinic acid: An endogenous metabolite that produces axonsparing lesions in rat brain. Science 219: 316318.

57. SchwartzkroIn, P. A., AND D. D. KunkEL. 1982. Electrophysiology and morphology of the developing hippocampus of fetal rabbits. J. Neurosci. 2(4): 445-462.

58. Shinohara, K., T. Nishikawa, K. Yamazaki, and K. TAKahaSHI. 1990. Ontogeny of strychnine-insensitive $\left[{ }^{3} \mathrm{H}\right]$ glycine binding sites in rat forebrain. Neurosci. Lett. 105: 307-311.

59. Shinohara, K., T. Nishikawa, S. IshiI, K. Yamazaki, and K. TAKAHASHI. 1989. Embryonic and postnatal development of $N$ (1-[2-thienyl]cyclohexyl) $\left[{ }^{3} \mathrm{H}\right]$ piperidine binding sites in rat forebrain homogenates and slices. Neurosci. Lett. 107: 307-312.

60. SquIRES, R. F. 1983. Benzodiazepine receptor multiplicity. Neuropharmacology 22: 1443-1450.

61. Steiner, H. X., G. J. McBean, C. Kohler, P. J. Roberts, and R. SCHWARCZ. 1984, Ibotenate-induced neuronal degeneration in immature rat brain. Brain Res. 307: 117-124.

62. Stone, T. W. 1985. Differences of neuronal sensitivity to amino acids and related compounds in the rat hippocampal slice. Neurosci. Lett. 59: 313-317.

63. SWanN, J. W., AND R. J. Brady. 1984. Penicillin-induced epileptogenesis in immature rat CA3 hippocampal pyramidal cells. Dev. Brain Res. 12: 243-254.

64. Thomson, A. M., D. C. West, ANd D. Lodge. 1985. An $N$ methyl-D-aspartate receptor mediated synapse in rat cerebral cortex: A site of action of ketamine? Nature (London) 313: 479481.

65. Tremblay, E., M. P. Rosin, A. Represa, C. Charriaut-MarLANGUE, AND Y. BEN-ARI. 1988. Transient increased density of NMDA binding sites in developing rat hippocampus. Brain Res. 461: $393-396$.

66. Watkins, J. C., AND R. H. Evans. 1981. Excitatory amino acid transmitters. Ann. Rev. Pharmacol. Toxicol. 21: 165-2040.

67. Young, A. B., J. T. Greenamyre, Z. Hollingsworth, R. ALBIN, C. D'Amato, I. Shoulson, AND J. B. PENNEY. 1988. NMDA receptor losses in putamen from patients with Huntington's disease. Science 241: 981-983. 